
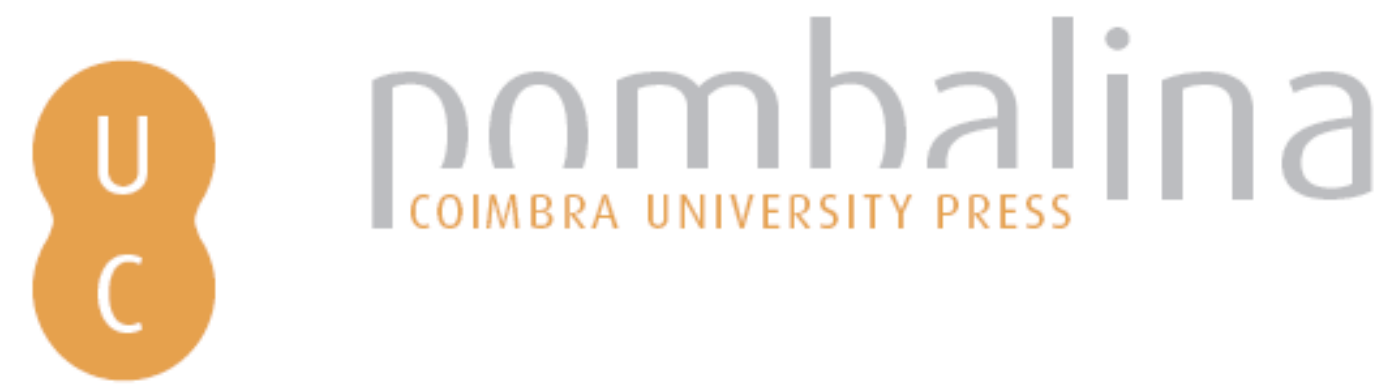

\title{
17 years of wildfire detection and management supported by an optical sensor system: field report from Germany's Brandenburg national forest, one of Europe's top wildfire regions at risk
}

\author{
Autor(es): $\quad$ Engel, Raimund
}

Publicado por: Imprensa da Universidade de Coimbra

URL persistente:

URI:http://hdl.handle.net/10316.2/44549

DOI:

DOI:https://doi.org/10.14195/978-989-26-16-506_32

Accessed : $\quad$ 26-Apr-2023 11:20:46

A navegação consulta e descarregamento dos títulos inseridos nas Bibliotecas Digitais UC Digitalis, UC Pombalina e UC Impactum, pressupõem a aceitação plena e sem reservas dos Termos e Condições de Uso destas Bibliotecas Digitais, disponíveis em https://digitalis.uc.pt/pt-pt/termos.

Conforme exposto nos referidos Termos e Condições de Uso, o descarregamento de títulos de acesso restrito requer uma licença válida de autorização devendo o utilizador aceder ao(s) documento(s) a partir de um endereço de IP da instituição detentora da supramencionada licença.

Ao utilizador é apenas permitido o descarregamento para uso pessoal, pelo que o emprego do(s) título(s) descarregado(s) para outro fim, designadamente comercial, carece de autorização do respetivo autor ou editor da obra.

Na medida em que todas as obras da UC Digitalis se encontram protegidas pelo Código do Direito de Autor e Direitos Conexos e demais legislação aplicável, toda a cópia, parcial ou total, deste documento, nos casos em que é legalmente admitida, deverá conter ou fazer-se acompanhar por este aviso.

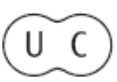




\section{ADVANCES IN}

\section{FOREST FIRE RESEARCH}

\section{8}

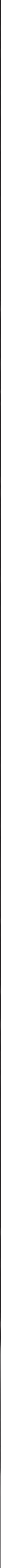




\title{
17 years of wildfire detection and management supported by an optical sensor system: Field report from Germany's Brandenburg national forest, one of Europe's top wildfire regions at risk
}

\author{
Raimund Engel \\ Chief Forester \& Wildfire Protection Officer of the state of Brandenburg \\ State Forest Administration Brandenburg (Landesbetrieb Forst Brandenburg) Heinrich-Mann- \\ Allee 103, Building 5, 14473 Potsdam, Germany, \{raimund.engel@lfb.brandenburg.de\}
}

\begin{abstract}
When it comes to wildfires in Europe, people usually think about southern countries, such as Spain, Portugal or Italy. However, parts of northern and northeastern Germany have been classified by the European Union as top regions at risk of wildfires. The state of Brandenburg has more than one million hectares of forest, which is equal to $37 \%$ of the state area. Dry and sandy soil means poor growth conditions, and only undemanding plants may be cultivated with reasonable effort. That's why monoculture pine forests make up $78 \%$ of all woods in this area. Precipitation easily permeates the sandy soil while fires burn the extremely dry ground, fueled by liquid resin, needles and forest litter that does not decompose. This is particularly problematic since Brandenburg was a battleground of the final phase of World War II and a military training ground for more than 100 years. The region was contaminated by hundreds of thousands of tons of unexploded artillery grenades and bombs. About $36 \%$ of the entire state and $50 \%$ of the woodland is still heavily polluted with old weapons posing major risks to the civilian population and particularly to fire fighters. Early wildfire detection is crucial under these circumstances, and generations of human fire spotters worked for decades using a dense network of watchtowers. Due to extremely high maintenance costs of these watchtowers and due to difficult labor legislation, the automatic remote surveillance system FireWatch was introduced in 2001. Today human fire spotting is history; 108 sensors are operating successfully and have proven to be technologically efficient. Plenty of detailed statistics haven been collected for decades giving evidence that the burnt area per hectare of a fire has been reduced tremendously since the installation of FireWatch and that the system has clearly outperformed the human spotter from a long-term perspective.
\end{abstract}

Keywords: early wildfire detection; forest fire management; climate; wildfire suppression; forest fire risk; monoculture forests; optical sensors; weapons and ammunition pollution; preservation of environment, safety and order

\section{The Threat of Wildfires}

\subsection{Climate and Geography}

Brandenburg is the most eastern state of the federal republic of Germany sharing a border of 252 $\mathrm{km}$ with the republic of Poland. Brandenburg is one of the most forested states of Germany encompassing 1.1 million hectares of forest of which pine trees dominate more than three quarters.

The sandy soil is characterized by the glacial period. The moraine landscape is slightly hilly, yet the flat outwash plains dominate the area, intermittent by numerous aquiferous drainage and by glacial valleys. Because of its eastern border location, the majority of the state is continentally influenced by climate. Only the northern and northwestern part of Brandenburg is characterized an oceanic climate (sub-Atlantic). Low precipitation and extreme temperature differences affect the continental climate. In the long-term average, precipitation in Brandenburg is below $500 \mathrm{~mm}$ per year. Influenced by location and climate, vast pine tree forests dominate the landscape. Based on these prerequisites, the wildfire risk in Germany is the highest in Brandenburg.

In the beginning of the 1990's, the European Commission categorized the forests of Brandenburg to be of high and highest wildfire risk, which is comparable to many Mediterranean regions. 


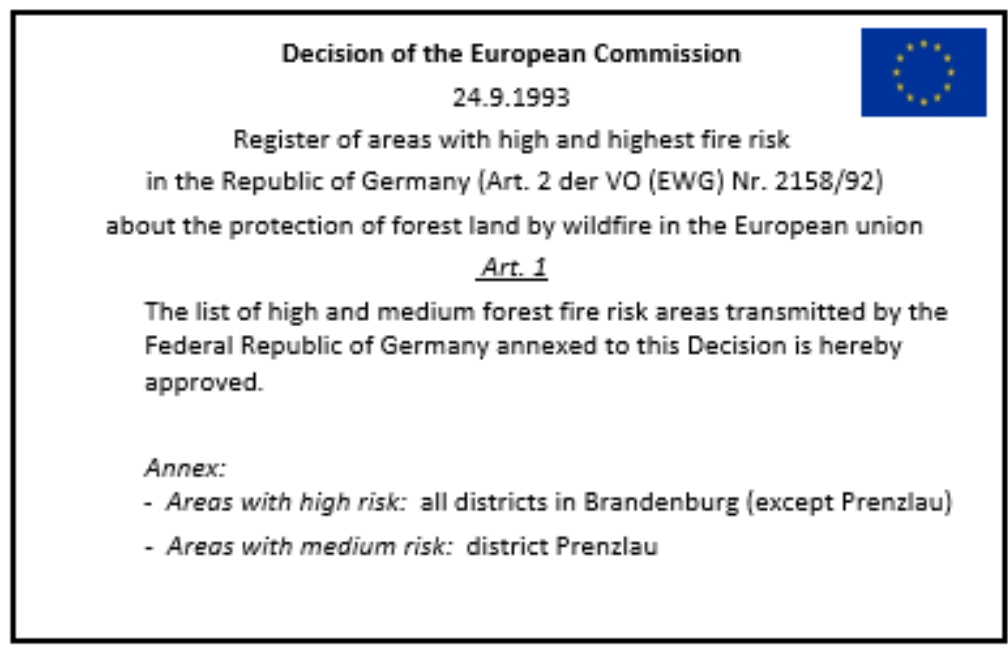

Figure 1 - Wildfire risk areas in Germany, decision of the European Commission

In a nationwide comparison, records of the last decades show that the Brandenburg forests burn most frequently. Even though not as many wildfires burned in the last years as in 2003 during the hottest summer of the century, still a yearly average of 230 wildfires burned in Brandenburg alone. Additionally, the many field and wasteland fires are not included in the forest administration's statistics.

Table 1 - Wildfire Statistics of the state of Brandenburg (1975-2016)

\begin{tabular}{|c|c|c|c|c|c|}
\hline Year & Quantity & Area (ha) & $\begin{array}{c}\text { Average Area } \\
\text { (ha) }\end{array}$ & $\begin{array}{c}\text { Fires }>100 \text { ha: } \\
\text { Quantity }\end{array}$ & $\begin{array}{c}\text { Fires > } 100 \text { ha: } \\
\text { Area (ha) }\end{array}$ \\
\hline 1975 & 487 & 923 & 1.9 & 1 & 144 \\
\hline 1976 & 1259 & 2296 & 1.82 & 3 & $115 ; 279 ; 365$ \\
\hline 1977 & 106 & 56 & 0.53 & & \\
\hline 1978 & 434 & 367 & 0.85 & & \\
\hline 1979 & 323 & 194 & 0.6 & & \\
\hline 1980 & 407 & 302 & 0.74 & & \\
\hline 1981 & 278 & 276 & 0.99 & & \\
\hline 1982 & 1161 & 1251 & 1.08 & 1 & 173 \\
\hline 1983 & 641 & 1688 & 2.63 & 3 & $184 ; 273 ; 478$ \\
\hline 1984 & 284 & 317 & 1.12 & & \\
\hline 1985 & 300 & 184 & 0.61 & & \\
\hline 1986 & 384 & 207 & 0.54 & & \\
\hline 1987 & 147 & 74 & 0.51 & & \\
\hline 1988 & 549 & 381 & 0.69 & & \\
\hline 1989 & 653 & 337 & 0.52 & & \\
\hline 1990 & 477 & 450 & 0.94 & 1 & 196 \\
\hline 1991 & 471 & 414 & 0.88 & 1 & 121 \\
\hline 1992 & 1024 & 1296 & 1.27 & 2 & $115 ; 242$ \\
\hline 1993 & 510 & 656 & 1.29 & 2 & $136 ; 295$ \\
\hline 1994 & 532 & 582 & 1.11 & 1 & 166 \\
\hline 1995 & 406 & 139 & 0.34 & & \\
\hline 1996 & 434 & 248 & 0.57 & & \\
\hline 1997 & 452 & 161 & 0.36 & & \\
\hline 1998 & 315 & 83 & 0.26 & & \\
\hline 1999 & 375 & 134 & 0.36 & & \\
\hline
\end{tabular}




\begin{tabular}{|l|c|c|c|c|c||}
\hline 1999 & 375 & 134 & 0.36 & & \\
\hline 2000 & 422 & 186 & 0.44 & & \\
\hline 2001 & 174 & 35 & 0.2 & & \\
\hline 2002 & 200 & 34 & 0.17 & & \\
\hline 2003 & 679 & 600 & 0.88 & & \\
\hline 2004 & 197 & 87 & 0.44 & & \\
\hline 2005 & 163 & 50 & 0.31 & & \\
\hline 2006 & 368 & 312 & 0.85 & & \\
\hline 2007 & 201 & 45 & 0.22 & & 197 \\
\hline 2008 & 321 & 353 & 1.1 & 1 & \\
\hline 2009 & 243 & 86 & 0.35 & & 237 \\
\hline 2010 & 208 & 295 & 1.42 & & \\
\hline 2011 & 221 & 42.9 & 0.19 & & \\
\hline 2012 & 234 & 76 & 0.32 & & \\
\hline 2013 & 161 & 45.3 & 0.28 & & \\
\hline 2014 & 115 & 27.4 & 0.24 & & \\
\hline 2015 & 315 & 321 & 1.02 & & \\
\hline 2016 & 232 & 92.3 & 0.4 & & \\
\hline \hline
\end{tabular}

\subsection{Pollution: Left-Over Military Ammunition, Bombs and Grenades}

But that's not all when it comes to forest fire danger in Brandenburg. Aside from the climatic and geographic extremes and, consequently, the occurrence of pure pine stand, there is another variable at play: the pollution of ammunition in forests, fields and waters as well as in villages and cities. Nationwide, the state of Brandenburg shows the highest number of regions laden with ammunition and weapons.

Today, approximately 392,000 hectares of Brandenburg's total area size are still categorized as "polluted." Especially the regions of the former $1^{\text {st }}$ and $2^{\text {nd }}$ front lines of German and Soviet armed conflicts during World War II along the river Oder, at Seelow Heights, in Halbe and in close vicinity to the city of Berlin are affected. In terms of counties, this especially applies to Märkisch-Oderland, Oder-Spree, Dahme-Spreewald and Teltow-Fläming. On the following map, areas suspected of weapon pollution are depicted in red. However, the assumption that other areas are laden with ammunition and weapons is not ruled out. 


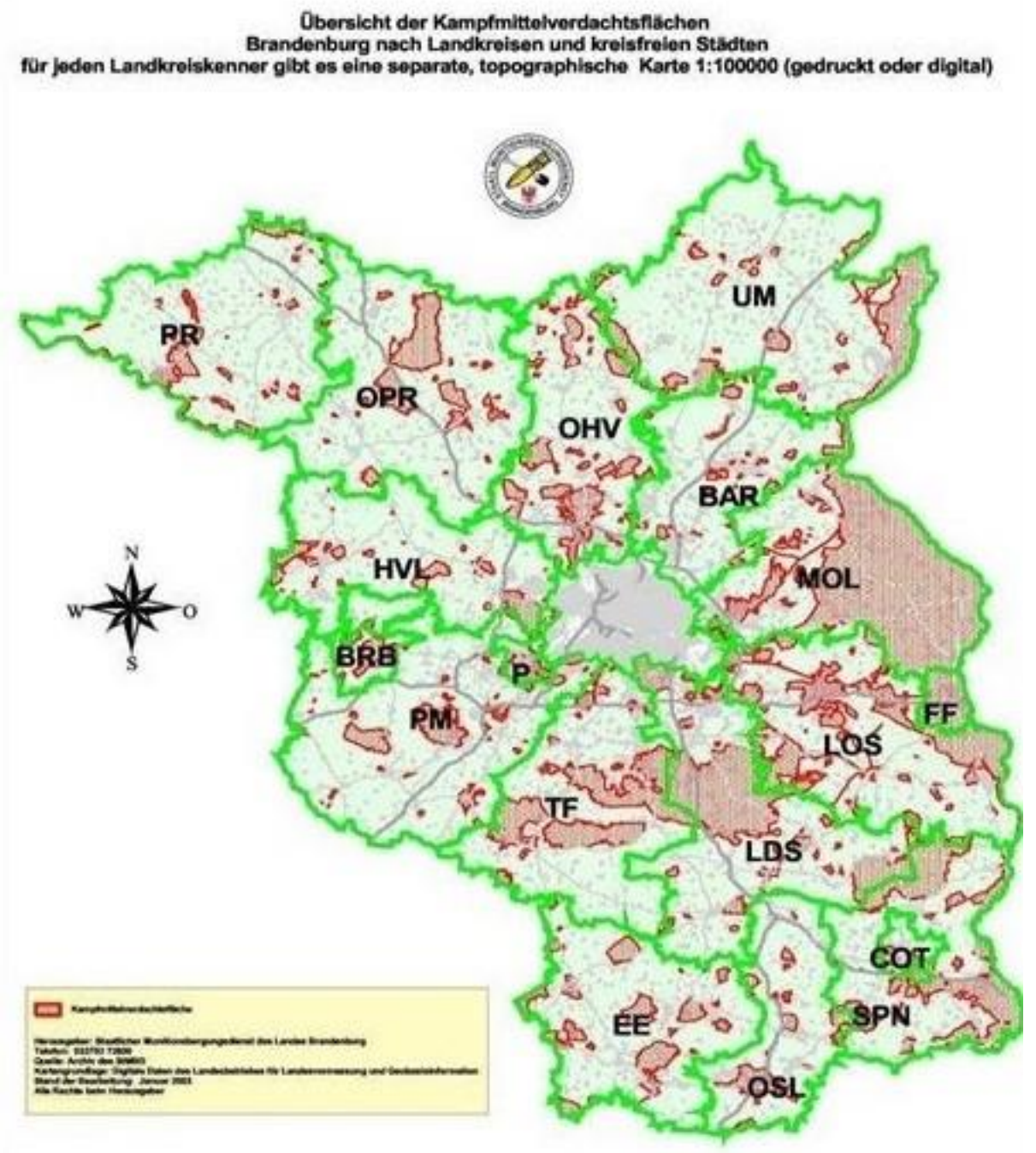

Figure 2 - Areas suspected of weapon pollution (red) in the state of Brandenburg

Located in Märkisch-Oderland, the Seelow Heights are mainly used for agriculture, but the suspected areas in the counties of Teltow-Fläming, Dahme-Spreewald and Oder-Spree are heavily forested. Additionally, ammunition from World War I as well as from the many Soviet military training grounds can be found here. In conclusion, almost all of Brandenburg is categorized as vulnerable.

Even though the weapons disposal service (Kampfmittelbeseitigungsdienst, KMBD) of Brandenburg collects, transports and disposes of hundreds of tons of different weapons every year, such as explosive and incendiary bombs, mines, grenades, and a vast amount of ammunition, the wildfires still pose a high threat.

Plenty of small caliber bullets covered with phosphor on their tips can be found. These are called tracer bullets because they helped trace the shooter's trajectory. Many bullets however did not burn down or are left over from trenches, bomb craters or simply in the woods.

With temperatures of only $23^{\circ} \mathrm{C}$ and an influx in oxygen, the phosphorous tip can easily ignite. If enough fire load (brushwood, dead grass) is available, it could lead to a wildfire in areas with no roads and pathways, even in early spring. Especially in polluted woods, plenty of wildfires occur that ignite due to the left-over weapons. In the south, the percentage of weapons as a cause of wildfires is in the two-digits every year. 


\subsection{Firefighting in Polluted Woods}

Forest fire fighting in areas that are heavily polluted with left-over weapons is considered as difficult and as too dangerous for ground-based firefighting. Even a surface fire can lead to small caliber weapons detonating and exploding.

If the region in question is polluted in such a way that a detonation is expected or inevitable, the firefighting forces will not be deployed for the sake of the fighters' safety. Only the nearest official safety zones would be accessed in order to fight the blaze with fire monitors (water cannons).

Yet, as a consequence the areas inside the safety zones burn less controlled. The damaged and partially destroyed wooded sections in those areas increase due to the fire, hence, the usage of fire fighting forces and resources is prolonged to multiple days if not weeks.

For example, an area the size of 160 hectares burned down near Jüterbog (County Teltow-Fläming) in 2015, and 250 hectares burned in Lieberose in 2017.

At the same time, firefighting helicopters are not an alternative as slivers of detonating ammunition can be disseminated in any direction. As a result, the aerial crew could equally be in danger above the blaze.

For a few years now, the county Teltow-Fläming has been using a privately-owned firefighting tank for areas heavily polluted with ammunition. Due to two fire monitors, the tank allows the firefighting crew to effectively attack the fire.

Managers will continuously be challenged to fight forest fires. However, one thing is clear: safety first. In areas that are heavily polluted with ammunition, risky firefighting is never justified.

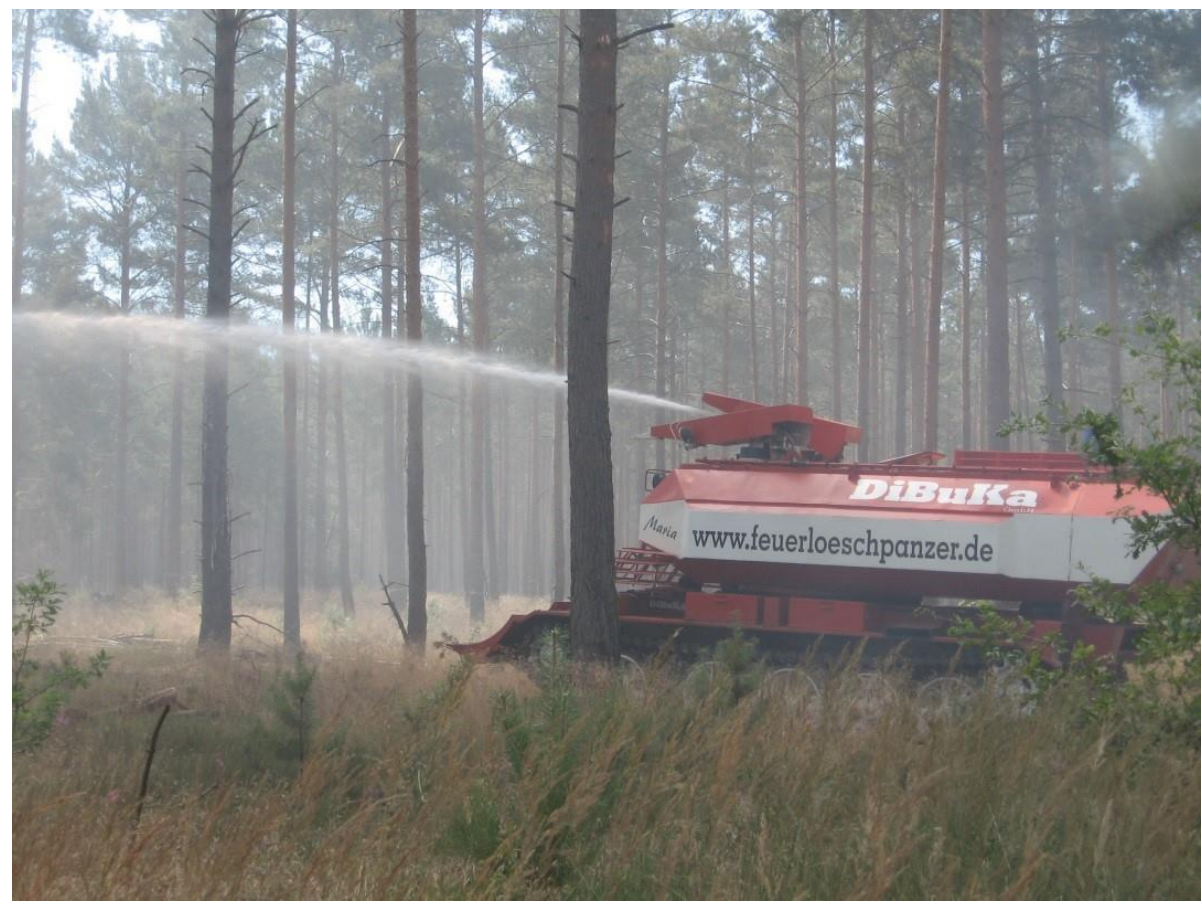

Figure 3 - Fire tank in action

\section{Wildfire Detection Methods: Then and Now}

\subsection{Human Fire Spotting}

While wildfire fighting as a method of wildfire protection is part of the municipalities' managerial obligations, the Brandenburg forest legislature decided that preventative wildfire protection is under direct obligation of the forest owners. This includes managing firebreaks of 30 meters wide and of 300 
meters wide, as well as installations and upkeep of extinguishing water sites. Forest owners are also obligated to control forests that are vulnerable to wildfires, especially after a fire that spread onto neighboring properties. The European Union, the federation and the state of Brandenburg support forest owners with adequate aids and funds for preventative wildfire protection.

While wildfire fighting as a method of wildfire protection is part of the municipalities' managerial obligations, the Brandenburg forest legislature decided that preventative wildfire protection is under direct obligation of the forest owners. This includes managing firebreaks of 30 meters wide and of 300 meters wide, as well as installations and upkeep of extinguishing water sites. Forest owners are also obligated to control forests that are vulnerable to wildfires, especially after a fire that spread onto neighboring properties. The European Union, the federation and the state of Brandenburg support forest owners with adequate aids and funds for preventative wildfire protection.

Early wildfire detection has been and continues to be the states' obligation no matter whose property the forests are.

Until 1989, Brandenburg had a network of 133 fire lookout towers; employees of the forest administration would work these towers on days marked with high fire danger. Under sometimes extreme working conditions, these employees would spend up to 12 hours on top of fire lookout towers at heights of 36 meters and in direct sun. Their job was to spot smoke plumes on the horizon with their binoculars and to pin-point the location by using iron sights. By telephone or radio, they would pass on the degrees to the nearest forest office where administrative employees would try to determine the closest tower to perform a cross bearing, resulting in pin-pointing the exact fire location on a map.

As early as 1995, the Brandenburg forest administration was contemplating how to organize and implement early wildfire detection more efficiently.

It soon showed that the system of staff-intensive fire watch towers would not be economically feasible in the long-term. Additionally, working these towers constituted an intense health concern for employees. The structural preservation of those towers would be a continuous financial burden for the forest administration that would be incalculable. An alternative solution for the early wildfire detection was needed soon.

\subsection{Automated Early Wildfire Detection: FireWatch}

In 1994, the Brandenburg state forest administration initiated first pilot projects revealing how wildfires could be detected faster and more efficiently by automated early wildfire detection systems. The German Aerospace Center (Deutsches Zentrum für Luft- und Raumfahrt e.V. (DLR)) was won as partner of the project. Researchers of the DLR relied on space technology that was already developed. Cameras that detect smoke and that were originally built for the exploration of Mars and other planets, were reconstructed and combined with a specialized image processing software. Starting in 1997 in the Lausitz border region in the southeast of the state of Brandenburg, an extensive pilot project funded by the INTERREG program of the European Union was installed.

The early wildfire detection optical sensors that detect smoke rising right above treetops clearly showed signs of technological possibilities and were a right step into the future.

It was clear for every long-term human spotter: the optical sensor works better than any human and could never become tired. Day after day, the sensors deliver consistent high-quality images and the specifically-programmed smoke detection software allows for timely and safe wildfire detection.

In 2003, the state forest administration had a complete FireWatch surveillance network installed. At the same time, the Brandenburg forest legislation was amended, and the statutory basis for the protection against wildfires added that from then on, the state of Brandenburg would use an early wildfire detection system in vulnerable forested areas. Forest owners had to comply with the 
installation and operation of the early wildfire detection system (see: $\S 20$ section 3 of forest legislature state of Brandenburg ${ }^{1}$ ).

In 2006, after only 3 years of operation, Brandenburg's forests (over 1 million hectares) were surveilled by 108 optical sensors. Neighboring states, such as Saxony, Saxony-Anhalt and Mecklenburg-Western Pomerania followed and installed the early wildfire detection system FireWatch. Now, this system consists of a cross-border network of 178 sensors in regions of the Federal Republic of Germany with the highest wildfire danger.

The sensor rotates $360^{\circ}$ every 4-6 minutes and scans an area of up to $700 \mathrm{~km}^{2}$. Up to 16.000 grey scale values are compared in sections. A smoke plume that derives from burned organic material has a unique pattern, unique coloration, and dynamics of development that are all detected by the software. If incoming values equate to those of a smoke plume, the system will signal an alarm at the control center. The data of each of the optical sensors are transmitted in real time via radio relay to the control center, of which there are currently 6 in the state of Brandenburg. An operator, a specially qualified forest administration employee of the state, can watch up to 8 systems and those incoming alarms.

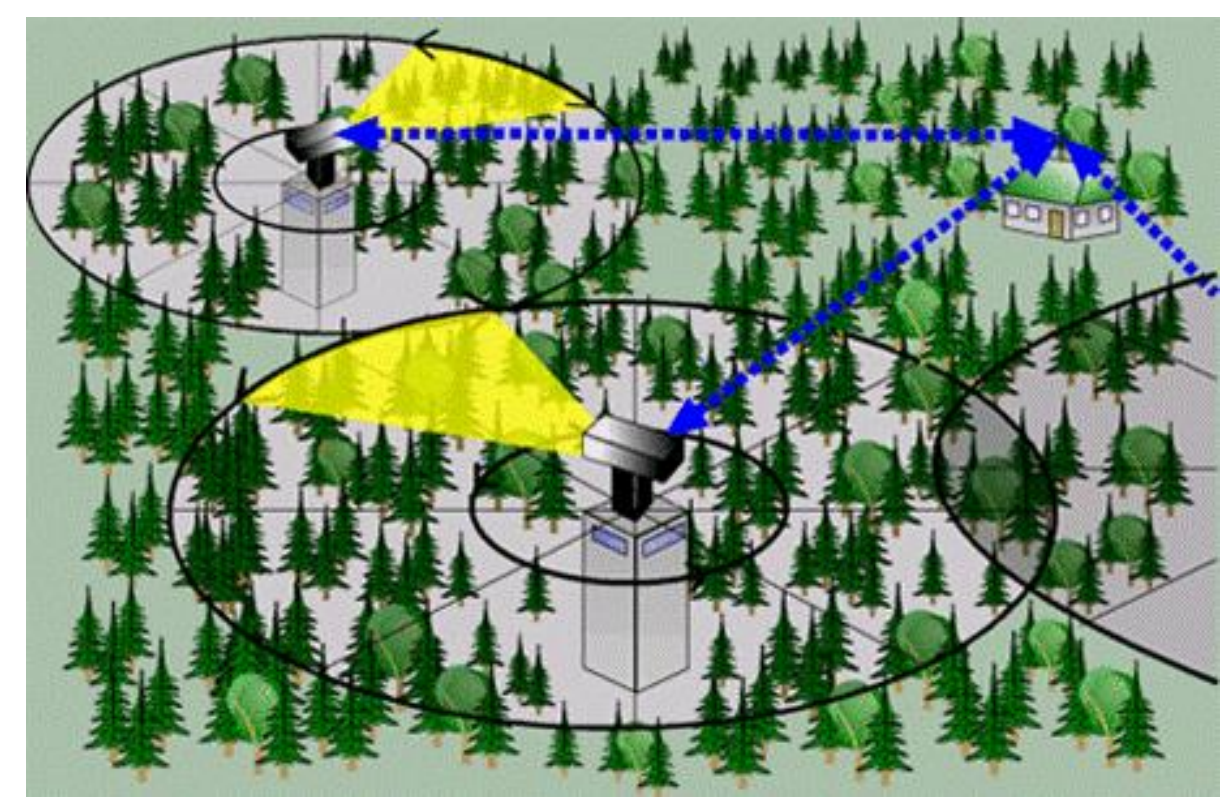

Figure 4 - Animated simulation of forest covered by FireWatch - 360 degree rotation

In the following two years, Brandenburg will be upgrading the existing systems of automated early wildfire detection to the newest generation of optical sensors and smoke detection software. The technological infrastructure of data transmission will also be updated. In order to effectively work and use synergistic effects, it seems plausible to equally reduce the numbers of control centers. Starting in 2020, alarms of all 108 optical sensors will be analyzed in only two interconnected control centers. The field-tested optimization of the software makes it possible to watch additional sensors at one work station. From then on, up to 18 systems can be watched by one operator, but the usual workload for one operator would be 12 systems.

${ }^{1}$ Waldgesetz des Landes Brandenburg (LWaldG) vom 20. April 2004 (GVB1. I S. 137), zuletzt geändert durch Art. 1 des Gesetzes vom 10. Juli 2014 (GVB1. Nr. 33) 
Incoming alarms of each sensor appear in a panorama image. At the same time, the location of the potential fire is optically depicted by a signal beam on a topographic map on a second monitor. Once another sensor registered a detection, an automatic cross bearing follows aiding in pin-pointing the exact location of the fire.

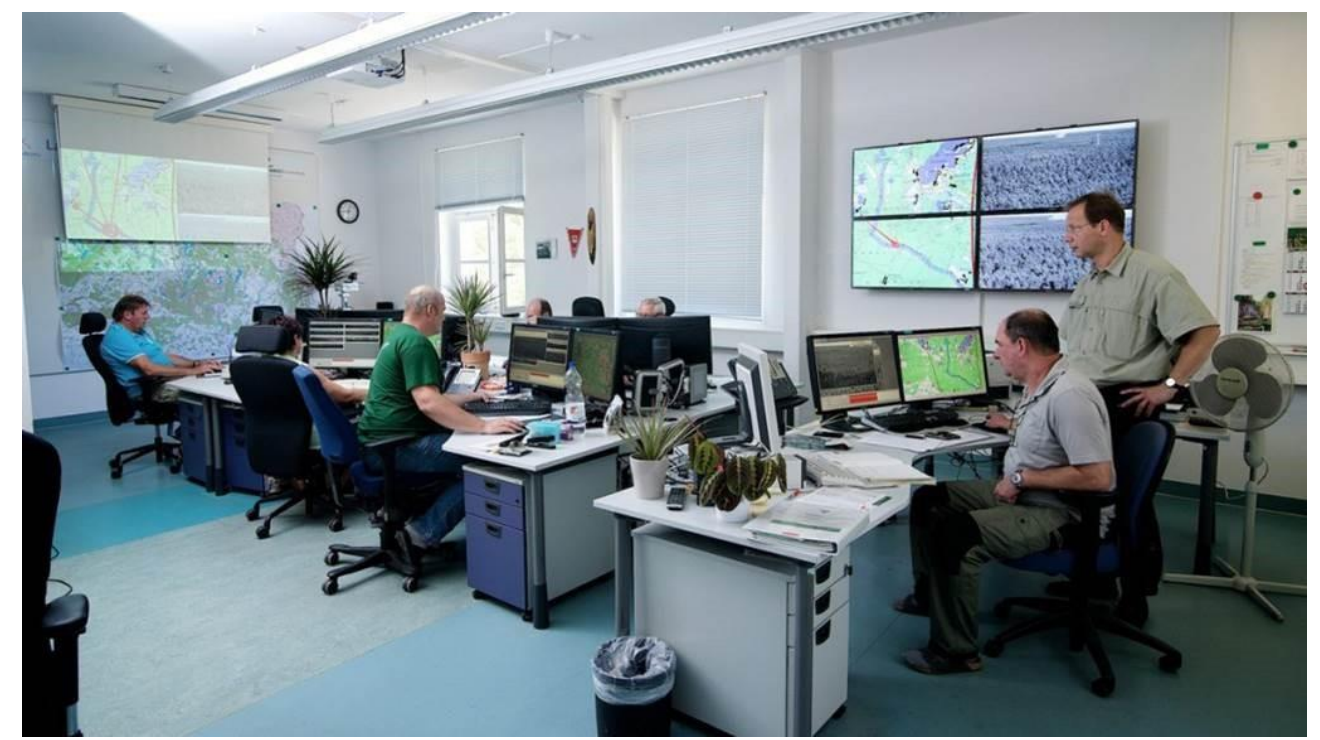

Figure 5 - Wildfire control center in Wünsdorf, Brandenburg

If the detected smoke is confirmed to be a forest fire, the regional headquarters of the fire and emergency services are digitally informed. Aside from the basic data (date, time and forest address), headquarters also receive the exact coordinates (in all common coordinate formats) as well as a current image derived from the sensors along with a map showing the cross bearing.

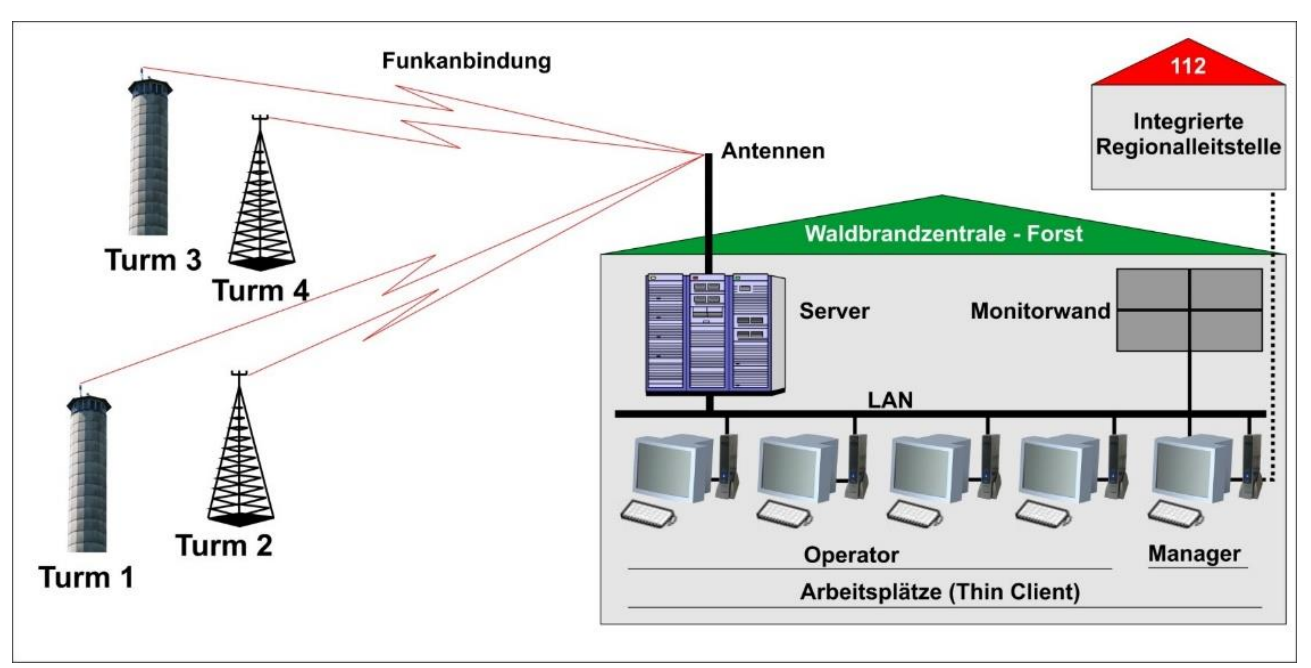

Figure 6 - Network of sensors, wildfire control center \& emergency and fire services

For more details, the map also shows all available extinguishing water sites and the trails that are open year-round for trucks. All forested areas in the state of Brandenburg have an official forest address, which is comparable to a regular street address. That way, a wildfire can be located not only geographically by a map but its location can also be verbally described.

It is probably only a matter of time, or better a matter of technological development, until wildfire detection data can be transferred from regional headquarters to the emergency vehicles. The 
coordinates could then be implemented into the navigation systems. The Brandenburg state forest administration has already now gathered all passable trails in a trail information system. Therefore, navigation of all emergency vehicles outside the public road network would be viable.

An essential component in the process of evaluating incoming automated alarms of the early wildfire detection is the so-called "mini clip." Within seconds, the operator at the control center receives a moving image showing the smoke development so he can visualize the direction and the speed of fire propagation. This information helps the forest employees and the fire department to be prepared for the situation before having arrived at the site of fire.

The season of wildfire surveillance usually starts on March $1^{\text {st }}$ and ends on September $30^{\text {th }}$ of every year. Working shifts for each employee of the states' forest administration are posted in the control center. Weather pattern and forecast determine every wildfire danger level and therefore, also determine working shifts at the control center. When the danger rating is at 3, mid-level, employees at the control center work from $10-18$ o'clock. Once the rating increases, the working hours also increase. When it is at level 4 - high danger - working hours are extended until 19 o'clock, and when it is level 5 - highest danger - hours are until 20 o'clock. With extreme weather conditions working shifts can even be extended until dark.

While IQ wireless $\mathrm{GmbH}$, manufacturer of the system, have developed and released day and night detection technology onto the market already, Brandenburg is only focused on detection during the day. Out of 100 wildfires, 80 ignite during the day between 10 and 18 o'clock. With only a few exceptions per year, humidity as well as ground moisture both decrease the chances of a wildfire igniting at night. Statistics currently don't justify the addition of a night system to the existing day detection system in Brandenburg.

\section{Conclusion and Look to the Future}

After 17 years of using FireWatch in Brandenburg, the wildfire areas have been reduced successfully due to this special surveillance technology. In the last years, the average wildfire area has decreased to under $3000 \mathrm{~m}^{2}$ in size. The earlier the wildfire is detected and the earlier the rescue services are alerted with an exact fire location, the earlier the targeted firefighting can be initiated. Reasonable and available usage of forces and resources can get an initial ground fire under control and extinguish it. If a wildfire has developed into a full fire blaze with crown fires, it is clear that the fire department would have to work at it for days.

With the early wildfire detection system FireWatch, the Brandenburg state forest administration is contributing substantially to the protection of forests.

By now, climate change has also impacted Europe in many ways. Increasing temperatures and longlasting heat waves will increase in the foreseeable future. Temperatures of $40^{\circ} \mathrm{C}$ will most likely not be an isolated incident. Wildfire danger will also rise. Therefore, it is crucial to try everything so that wildfires do not turn into catastrophes. Wildfires need to be detected and located as early as possible. Only then, catastrophes can be prevented.

Early wildfire detection - a substantial contribution to preserving our environment and to maintaining public safety and order.

\section{References}

Deutsches Zentrum für Luft- und Raumfahrt e.V. (2005) Wie DLR-Forscher Arbeitsplätze in der Wirtschaft schaffen. DLR Nachrichten 112, 12.

Engel R (2009) Brandenburg setzt flächendeckend auf „Fire Watch.“ AFZ - Der Wald 12, 632-634. 
Engel R (2016) Wenn es brennt, zählt jede Minute. Feuerwehr - Magazin, Sonderheft Wald-und Flächenbrände 1, 14-19.

Engel R (2016) Brände auf militärischen Flächen. Feuerwehr - Magazin, Sonderheft Wald- und Flächenbrände 1, 93-95.

Engel R (2017) 15 Jahre Waldbrandfrüherkennung Fire Watch im Land Brandenburg. AFZ - Der Wald 18, 21-22.

Feldmann M (2015) Früh zum Forst gekommen - Der Waldbrandschutzbeauftragte Brandenburgs. Behörden-Spiegel 11, 3.

Goodrich D (2010) FireWatch Australia Stage 2 Trial Proposal: Proven Automatic Bushfire Detection for the $21^{\text {st }}$ Century. FireWatch Australia, Australian National FireWatch Early Detection Network. (Sydney, Australia)

Gräser G (1996) AWFS: Elektronik für den Wald. Berliner Feuerwehr. (Berlin, Germany)

Hartung W, Erlemeier T (2001) Automatisiertes Waldbrandfrüherkennungssystem statt konventioneller Feuerwachtürme. Forsttechnische Informationen (FTI) 4, 48-49.

Hartung W, Gruner R (2000) Weltraumtechnologie für die Waldbrandfrüherkennung. AFZ - Der Wald 7, 388-389.

IQ wireless GmbH (2010) FireWatch - Produktinformation. IQ wireless GmbH. (Berlin, Germany)

IQ wireless GmbH (2012) Wo Rauch ist, ist auch ein Feuer: FireWatch - ein Waldbrandfrüherkennungssystem. IQ wireless GmbH. (Berlin, Germany)

Lachmann M (2012) Waldbrandstatistik der Bundesrepublik Deutschland für das Jahr 2011. Bundesanstalt für Landwirtschaft und Ernährung. (Bonn, Germany)

Landesvermessung und Geobasisinformation Brandenburg LGB (2007) Land Brandenburg in Zahlen und Karten. Landesvermessung und Geobasisinformation Brandenburg. (Potsdam, Germany)

Ministerium für Infrastruktur und Landwirtschaft MIL (2013) Daten zu Wald und Forstwirtschaft in Brandenburg. Ministerium für Infrastruktur und Landwirtschaft Land Brandenburg MIL. (Potsdam, Germany)

Ministerium für Ländliche Entwicklung, Umwelt und Landwirtschaft des Landes Brandenburg (2007) FireWatch - Erfahrungen und Ausblicke. Brandenburgische Forstnachrichten 130, 8-9.

Turnham J (2013) FireWatch Texas Product Information. FireWatch Texas, LLC. (Austin, Texas) 